\title{
"Running into Madness to Stay Sane": the Spirituality of Nature in the Autobiographical Texts of Female Prisoners from Goli Otok Prison Camp
}

\begin{abstract}
Taczyńska Katarzyna, "Running into Madness to Stay Sane": the Spirituality of Nature in the Autobiographical Texts of Female Prisoners from Goli Otok Prison Camp. "Poznańskie Studia Slawistyczne" 16. Poznań 2019. Publishing House of the Poznań Society for the Advancement of the Arts and Sciences, Adam Mickiewicz University, pp. 267-279. ISSN 2084-3011.
\end{abstract}

The text concerns the camp for political prisoners established in 1949 in Yugoslavia on Goli Otok island. This theme was almost entirely absent from public discourse before the 1980s, and real changes and developments in discussions about this part of the history of postwar Yugoslavia occurred only after Tito's death. Goli Otok as the largest and most infamous camp in communist Yugoslavia is considered a symbol, its name recognized as a synonym of a physical and psychological system for destroying people. In the text I analyze autobiographical texts written by women prisoners (such as Milka Žicina and Vera Cenić). A large number of female inmates were sentenced just for being related to or keeping close contact with a male "enemy of the state". Thus women were treated not as independent subjects, but as mothers, sisters and wives subordinate to male family members. The social exclusion of women prisoners and their families exacerbated the feeling of isolation and continued after leaving the camp. I am interested in the detail of the strategies of storytelling which are related to spirituality (focusing on nature) both during the period of isolation, when they searched for a way to survive it, as well as after release when the women tried to start a new life.

KeYwords: Goli Otok; Yugoslavia; women; memory; nature; animal studies

\section{Introduction}

Undoubtedly, in recent years a significant increase in publications on the presence and activity of women in the past has been observed in Central, Eastern and South-Eastern Europe (including the Balkans), yet many (especially female) researchers feel that in history women seem to be 
guests rather than hosts (v. e.g. Ubertowska, 2015, 7). In many cases their fates, actions and experiences are not taken into account in historical education which means that they function only in the shadow of the dominant narratives. The memory and memories of women who were prisoners in camps and prisons for Cominformists in Yugoslavia were also condemned to such a marginal role for many years. Cominformists were political prisoners in re-education places (such as the camp created on the island of Goli Otok [Bare Island]) who were arrested as opponents of Yugoslav state policy after Yugoslavia was excluded from Cominform in 1948. We have to remember that Goli Otok prison camp is only one of many places of isolation intended for Cominformists that were established in Yugoslavia at that time. Because of its size and notoriety, Goli Otok became a symbol for all the contemporary prisons and camps for Josip Broz Tito's opponents (v. Kosić, 2009, 17; Михаиловић, 1990, XLII). The island was used as a re-education camp until 1954, but the majority of prisoners detained in connection with the resolution issued by Cominform were set free under an amnesty after the Communist Information Bureau was liquidated in 1956 (Gruenwald, 1987, 520). The last Cominformists left the island in 1960. At the end of 1956, the camp changed its character and became a prison designated primarily for criminals as well as for young people who attempted to escape to the West. The prison on Goli Otok island was finally shut down in 1988 (v. Taczyńska, 2016, 58-59).

The social and political situation dictated that the subject of Goli Otok prison camp was for many years a taboo both in Yugoslavia and abroad, in fact until the 1980s. However, the history of women arrested as Cominformists was suppressed further because their life stories and memoirs for many years had remained on the margin of researchers' interests. The fact that women were inmates in prisons and camps for Cominformists as well had previously been reported merely in dry figures. The memory had been dominated by a male-centered, universalizing narrative which had not included the stories and experiences of women, and this can be seen as a kind of oppression. The presentation of the female experience of prisons was reduced to modest references, often limited to short statements in the form of "Women were isolated in a separate camp" (Petranović, 1988, 232). ${ }^{1}$ It

1 "Žene su se nalazile u posebnom logoru." 
should be emphasized that among the female inmates, a significant number were convicted just for kinship or close contact with a male "enemy of the state". As we can see, women were not treated as independent subjects, but as mothers, sisters and wives, subordinate to male family members (Marković, 1987, 183; Jambrešić-Kirin, 2009; v. also Taczyńska, 2016, $117-123)^{2}$

The first chance to change the monolithic narrative came with a documentary series from 1989 Goli život (Bare Life) by Danilo Kiš and Aleksandar Mandić. It was the first documentary film dedicated to the issue of Goli Otok which distinctly showed that women were also inmates at the prisons and camps for Cominformists. Kiš - the narrator and interlocutor in the documentary - based the narration on the stories of two former female prisoners: Ženi Lebl and Eva Nahir Panić. All his attention was focused on the women's memories. For both women it was the first public statement they had made about the past. Although Kišss untimely death (and later also the civil war in Yugoslavia) halted social interest in women's experiences (there was no deeper debate or discussion on this subject), it did not stop the publication of the first texts on prison camps written by women. The first testimony written by one of Kiš's interlocutors from Goli život was published in 1990, a prose text by Ženi Lebl Ljubičica bela: Vic dug dve i po godine, 1990 (The White Violet: a Joke that Stretched for Two and a Half Years).

The next crucial step in the development of a camp discourse was at least partly facilitated by expanding the scope of the research through the application of new analytical theories, for instance feminist critical studies where the criterion of gender is a starting point. This perspective encouraged researchers to look for new texts written by women (which remain undiscovered in home archives), help see women's memoirs in a new light, organize the meanings hidden in them, (re)read senses, or (re)define values. This allowed for a reconstruction of the circumstances in which the works of Milka Žicina were created (Sve, sve, sve... [Everything, Everything, Everything...] 2002 and Sama [Alone] 2009), making it possible to investigate the reasons

\footnotetext{
${ }^{2}$ For instance, Eva Nahir Panić, who was imprisoned in the camp on the island Sveti Grgur, was arrested because of her husband's activity. The UDBA [State Security Service, Uprava državne bezbednosti] tried to force her to renounce her husband as a Soviet spy. V. more Taczyńska, 2018, 77-95.
} 
for their cultural marginalization (specific cultural violence) and to propose a new reading and thus shift these texts from a peripheral position to the center of the historical narrative. Before that the perception and interpretation of Žicina's output had been limited almost exclusively to two novels from the interwar period (Kajin put [Kaja's Road] 1934 and Devojka za sve [A Maid of All Work] 1940; for more about Žicina, v. Taczyńska, 2014; 2015). Looking at Žicina's literary works from today's perspective, we can say that this author was the first woman to write down her prison experience. She wrote the outstanding account of her stay in the camp (its artistic quality surpasses that of any other similar text) as early as the 1970s, but she had to hide the manuscript for many years. The memoirs were published after the author's death, first in magazines in 1993 and later as books (Вукмановић, 2009, 15; v. also Гароња Радованац, 2012).

The main topic of this text is a reflection on the issues of spirituality presented in the memories of former female prisoners through references to nature. Although in the published memories written by women we can distinguish several spheres related to spirituality (e.g. remembering masterpieces of literature, creating literature, reminiscences of family or home), due to the limited text frame, I would like to focus on analyzing just one aspect that dominates these memories: nature (flora and fauna). Such a decision results, on the one hand, from the semantics of the texts themselves in which the topic of nature takes a special place. On the other hand, the choice is dictated by the need to regain sensitivity by shifting attention from the human center to the margins of the natural world, the need to extend the discourse to non-anthropocentric themes. Such a view, I think, can enrich the current perception of camp texts and the horizon of seeing (reading) the experiences that have been described in them. This kind of approach provides an opportunity to introduce transformations in the memory of Goli Otok prison camp as well; it can help influence the nuances and expansion of memory and modify its character. The research also fits into the so-called perspective of post-humanism, in which relations with nature as a way of critical thinking become a necessity, required (or at least expected) from humanity deeply interfering in nature. ${ }^{3}$ As Éric Baratay emphasizes, a story

${ }^{3}$ An overview of Polish studies on ecological issues in literature can be found in Anna Barcz's work (Barcz, 2016). The French sociologist and philosopher Bruno Latour, 
broadened by a non-human factor becomes indispensable in the era of ecology and ethology, which in turn brings humanity back to nature (Baratay, $2018,38)$. Let us look at specific examples in the camp texts.

\section{Nature as a Calming Factor}

The presence of nature in memories can be considered at least from two perspectives. The first of them is more general, and appears as a frequent motif as a consoling and calming factor, not only during the isolation but also after release when the women tried to start a new life. Female texts show women's efforts to face the difficulties associated with the daily routine and the consequences of their imprisonment in the camps. The initial problem, recurring in many written memories, is how to find adequate language to describe the suppressed past. The beauty of nature and open spaces have a soothing effect on Milka Žicina. The author writes that home is not a good place for her to work through the drama of the past: "I cannot think about it at home. Our apartment is too merry: everything is clear, everything is free, nice people are around me, all this pleasantly distracts me from the thought of the terrible past. It has drawn me away for years. I leave the house and go wherever" (Žicina, 2002, 45). ${ }^{4}$ Yet the unprocessed trauma keeps eating at her. While she is writing down her memories, she keeps going out to get in touch with nature and take a break from the traumatic past. The unchanging and majestic nature of the mountains, especially those close to her heart like Tara (a mountain in Serbia), brings calmness into her life. Žicina shows an almost pantheistic approach when she is humbly raising her eyes towards the peaks. However, her attitude is also complemented by a strong need for the dialogue which the author holds with surrounding nature. The anthropomorphization of reality plays

a co-founder of the Actor-Network Theory (ANT), in the context of ecological issues designs a program of political ecology called "nature policy" (v. e.g. Latour, 2009). Also worth mentioning is the monograph by Piotr Krupiński (Krupiński, 2016), in which the author interprets the Holocaust-themed literature from the perspective of animal studies.

4 "Ne mogu o ovome misliti kod kuće. Preveselo je u našem stanu: sve je svetlo, sve je slobodno, sve mili ljudi oko mene, sve me to ugodno odvraća da mislim o ružnom prošlom. Godinama me odvraćalo. Idem od kuće, ma gde.” 
an important role in the reconstruction of her past. Talking to Tara during the process of writing allows her to organize the stream of her thoughts:

you are always your own and the same, no one could humiliate you; do you do it out of goodness or have you forgotten, or maybe it is by the force of your existence which nobody's whim can change, that you state so openly that shame does not fall on the one who has been inhumanly humiliated, but on the one who humiliated him. This is his disgrace (Žicina, 2002, 46). ${ }^{5}$

Moreover, in the most difficult moments when it is necessary to break the narrative, contact with nature makes the return to writing easier. Certain phenomena remind Žicina of the sounds and images that she encountered in the Stolac prison camp in Bosnia and Herzegovina where she was imprisoned from 1952 to 1955 . Although the story is difficult to write, she involuntarily returns to it, inspired by nature:

It is difficult to recall that. [...] I needed to be finally free from it. I went to the shore. The sea had been raging for three February days already, grey as the clouded sky, no trace of the blue Adriatic. [...] My ears were buzzing and ringing... Maybe there are quieter waves, maybe out there they are rolling more calmly, but approaching the shore they are rushing, threatening rows, foaming from haste and violence and from rage; with a raised white mane they gallop to the target wall, bounce violently high and... break down. [...] A deep crash similar to the dark underground roar of the earthquakes that I heard in Stolac many times (Žicina, 2002, 20). ${ }^{6}$

It can be added that positive aesthetic stimuli that came from contacts with the beauty of nature, allowing the inmates to briefly forget the ugliness of the camp and reminding them of life on the outside, were an important component of women's personal writings documenting the authors' stay in concentration camps during World War II (v. Nikliborc, 2010, 143).

5 “"[T]i si uvek svoja i ista, niko te nije mogao poniziti, da li se to iz dobrote praviš da ti to nije na umu, ili pak silinom svog postojanja, koje niko ćefom svojim ne može promeniti, tvrdiš, evo, otvoreno: ne pada sramota na onog koga su neljudski ponižavali, nego na onog koji je ta ponižavanja vršio. To je njegova sramota."

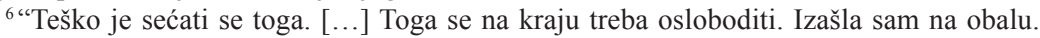
More je ljuto već treći februarski dan. Sivo kao i oblačno nebo, ni traga o plavom Jadranu. [...] U ušima mi je zujalo i zvučalo... Možda su tamo tiši, talasi, možda tamo mirnije plove, no približavajući se obali oni pojure, preteći špaliri, ogrivaju se od žurbe i sile i svog nekog besa, s nakostrešenom belom grivom dotutnje do cilja-stene, poskoče silovito visoko i... razbiju se. [...] Duboki tutanj sličan tamnom zemljotresnom podzemnom tutnju koji sam ne jednom slušala u Stolacu." 


\section{Nature as a (Close) Friend}

Nature in women's texts is also presented from another perspective. During the time of isolation, the enslavement and the necessity to comply with prison and camp rules forced prisoners to work out a way to survive. Although the conditions in which they lived were not conducive to openly defensive attitudes, they also prevented the formation of closer ties between the prisoners, especially in the first period of isolation. Yet women are always looking for ways to survive. One possibility is contact with nature. The beauty of nature can for a moment take the thoughts of prisoners away from what is happening here and now; it can offer them a breath of freedom and some hope - above all for their struggle to preserve humanity. As the literary scholar Sunčica Denić writes, a camp is a place where a person mostly stops existing as a human being because their personality is killed: "A place where a person is deprived of the ability to think, to create and to love. To live. And be judged for your thoughts, creativity and love. Only hatred is offered there and only weakness can be seen" (Денић, 2005, 61). ${ }^{7}$ Prisoners find even minimal contact with nature precious. When Vera Cenić accidentally discovers trees growing on a stony island during a march, she simply cannot take her eyes off them: "Something like a long-awaited festive day suddenly drops into my diminished field of vision and spills over; I breathe deeply, I do not believe in this green festival in front of my eyes, as if I were dreaming" (Ценић, 1994, 173). ${ }^{8}$ Another time, a single violet encountered by Cenić becomes the hero of her intimate encounter, which in her memory is recorded as a permanent, remarkable recollection:

Perhaps that's why I found it, a small wild violet in bloom. It grew and blossomed in the crevice of a rock. On a thin green stem, without leaves, a tiny blue-purple lonely flower. We look at each other. [...] I kneel before it and immerse myself in its scent. I kiss it. [...] This is the smell of hope. [...] I will keep this in my soul all my life,

7 “Место где се човеку одузима могућност да мисли, ствара и воли. Да живи. А суди му се због мисли, стваралаштва, љубави. Тамо се нуди само мржња и види само немоћ.”

8 "У мој осиромашени видик силно улази и шири се нешто као дуго очекивани празнични дан, дишем дубоко, не верујем у ту зелену светковину пред очима, као да сањам." 
I know. Nobody can take anything away from me anymore. I do not allow that anymore! (Ценић, 1994, 187-188). ${ }^{9}$

In Milka Žicina's works, the fragments describing how the author is building her relationship with nature are among the most beautiful passages in camp literature, clearly demonstrating the high artistic value of the texts and the exceptional sensibilities of the author. In the opinion of Garonja Radovanac, the descriptions of nature confirm that despite living through hell, Žicina managed to preserve her creative gift: "No torture was able to break the personality of the writer and, more importantly, the artist. The minimum of integrity and freedom was enough for her to leave [prison] as if she had kept everything" (Гароња Радованац, 2003, 144). ${ }^{10}$

Nature, anthropomorphized by Žicina, allows her to create an alternative to life in the reality of the camp, which acts as a springboard for her. The prisoner retreats into an inner world where she can freely think and talk with her companions: with the lark, passing from time to time overhead; with the stone she found in the grass; with the mountain peak watching over Stolac camp:

For Dedak [the mountain] is also my inner life. And you do not know about him. He is my friend. Dedak. I have the right to choose my friends - and what will you do to me? I have to be silent here, I am not allowed to make any sound, but in spite of that, I have someone to talk to - silently, but I have. I have the Lark, the Stone and Dedak. They are my friends... (Žicina, 2002, 63). ${ }^{11}$

To emphasize the importance and uniqueness of their presence, which forces her to reflect on the world and on herself, she writes the names of her friends with a capital letter: Ševa, or the Lark, Oblutak, or the Stone,

9 “Можда сам ја зато и нашла њу, малену, расцветану дивљу љубичицу. Никла је, порасла и процветала из пукотине камена. На танушној зеленој стабљичици, без лишћа. Модрољубичасти, мајушни усамљени цветак. Гледамо се. [...] Спустим се на колена пред њу и загњурим у њен мирис. Пољубим је. [...] То је мирис наде. [...] Носићу га [цвет] на длану душе кроз цео живот, знам. Више нико не може да ми одузме ништа. Више не дам!"

10 “Све тортуре нису успеле да сломе списатељкину личност и штавише, уметника. Минимум интегритета и слободе, био је довољан, да је она изашла, као да је сачувала све.”

11 “Jer, Dedak je takođe - moj unutrašnji život. A o njemu pojma nemate. On je moj prijatelj. Dedak. Imam pravo da sebi biram prijatelje i - šta mi možete? Ja moram ovde da ćutim, ni glas da mi se čuje ne sme, ali, u inat, ja imam s kim govoriti, nemušte doduše, ali imam. Imam Ševu, Oblutak i Dedaka. To su mi prijatelji..." 
and Dedak. In a camp dominated by violence, all the symptoms of joy of life which disrupt overwhelming sadness and suffering are seen as a gift. Thanks to the closeness of her new companions, Žicina sometimes allows herself even to joke; for example about the harshest prison punishment, i.e. breaking stones, calling this "work in the Stone Age".

Žicina devotes a lot of space in her text to the descriptions of gradual emergence of "friendship" with the representatives of nature. First, she talks about a surprising encounter with Oblutak (the Stone): "He lay in the trodden grass next to me. He showed himself when I was collecting spilled chippings. You could touch him, even hold him in your hand. And he was smooth, so smooth, pleasant and nice, so nice" (Žicina, 2002, 53). ${ }^{12}$ After a short while it turns out that between her and the stone has grown a strong "bond of understanding", thanks to which she is able to completely cut herself off from the current events:

He accepted everything, he understood everything and he did not give me away. It was hard to hide him in the evening. But they did not find him. So, thanks to his friendship, which I felt even when I did not have him in my hand, it was possible, standing in the pavilion when others were eating dinner [...], it was possible to go away somewhere in my head (Žicina, 2002, 53-54). ${ }^{13}$

The first contacts made with Dedak (the mountain) look slightly different. In the beginning Žicina looks at the mountain with distrust. She has the impression that the summit towering above the camp behaves like a king and an egoist to whom everything must be subordinated, and he looks down with a cold eye: "Dedak, a primitive who looks and does not see anything, busy with himself, conceited; only he is right about everything and no one else; flooded with light, happy with himself, he has achieved everything, he stonily lies above" (Žicina, 2002, 62). ${ }^{14}$ She even compares him to the

12 "Ležao je u ugaženoj travi odmah pored mene. Pokazao se kad sam uzbacivala na gomilu razasuti tucanik. Moglo ga se dodirnuti, čak podržati u ruci. A bio je gladak, gladak, prijatan, i mio, mio."

13 “'On je sve primao, sve shvatao i - nije me izdao. Bilo ga je teško sakriti uveče. No nisu ga otkrili. I tako, njegovim prijateljstvom, koje sam osećala i kad mi nije bio u ruci, moglo se, stojeći u paviljonu dok drugi ručaju [...] moglo se, dakle, sasvim odmaknuti nekuda."

14 "Dedak jedan, primitivac koji gleda a ne vidi ništa, zanet sobom, uobražen, samo on ima u svemu pravo i niko drugi, izukrštan svetlom, samozadovoljan, sve je postigao, čvrsto leži iznad." 
omnipotent, angry and infallible God of the Old Testament, at the same time accusing him - in her silent dialogues - of inaction in the face of what is happening in Stolac. When it seems that apart from disappointment and reluctance no more feelings will awake in her, she notices that the silent but persistent presence of the mountain in her life also has a good side - something that no authority can take away from her. Again, she looks shyly at Dedak, and the sight of his unwavering presence gradually fills her with calmness. As the text shows, Žicina is aware that she has induced in herself some peculiarity, strangeness, a kind of madness in that closed reality of hers, inaccessible to others. But she also knows that building an internal alternative world has been the only way out in a hopeless situation if she wants to keep the essence of herself: "Running into madness to stay sane. Running into my own madness to avoid going crazy" (Žicina, 2002, 108). ${ }^{15}$ The camp experience and naturalism (including also animism) are interwoven in human experience. Although we are dealing here with the anthropocentric perspective of the prisoner (the most natural one for a human being), relations with nature change significantly. There is no hierarchy, no rule and no human power, but the agential role of nature is clearly exposed. Žicina comes from her own human history, but she also tries to learn and approach the non-human point of view. The terms of the relationship with nature are not uni-directional but require mutual involvement: recognition; reacting, interacting and integrating, one into the world of the other (Baratay, 2018, 48).

The anthropomorphizing act is also clearly visible in Žicina's second text - Sama. During the first days of her stay in Glavnjača prison, the protagonist first focuses her thoughts on everyday life and routine realizing how much she longs for the banal activities that accompany them, for example, saying "Good morning": "What a great thing it is to greet someone in passing: 'Good morning'!” (Жицина, 2009, 22). ${ }^{16}$ A simple greeting is valued only when there is nobody to say it to. Then she slowly begins to look more closely at the surrounding space. Contact with the walls, the floor and even a piece of string makes this dead space take on a new meaning for her and shapes her emotional life. Again, we can see how a personal relationship is growing between her and the objects around, especially with the four walls.

15 "Pobeći u ludilo da bi ostao zdrav. Pobeći u svoje ludilo, da ne bi zaista poludio." 16 “Како је то велика ствар моћи некоме у пролазу рећи: Добар дан!” 
The space does not accept the prisoner as a friend: it torments her constantly, repeating the same piercing word: "alone, alone, alone". So Žicina feels somewhat compelled to become familiar with her opponents. She names the walls: Great (Veliki), Malicious (Zlobnik), Official (Zvanični), and Service (Službeni), and they get to know each other, they talk and argue. The individual names are closely related to the character of each wall. For example, Zlobnik, also sometimes called Mephistus, is described thus: "He growls all the time; no, he does not growl - just squeals, howls, until he is green with anger and evil and powerlessness" (Жицина, 2009, 28). ${ }^{17}$

Yet again, Žicina's involvement in the space around her makes her feel that she can separate herself from the prison nightmare. She is very much aware that no one among the guards or the management has the slightest power over her imagination. She is not sure if she can survive the next interrogation (which later also involved torture), but escaping into the world of imagination gives her the impression that she has won over her persecutors because she has something that they will never take away from her: "You have no power over this world. You rage, but you cannot do anything here" (Жицина, 2009, 97). ${ }^{18}$

\section{Conclusion}

Among historical or literary studies in the former Yugoslav countries, interest in animals or more broadly 'nature' is still a rarity. ${ }^{19}$ The analysis presented here is an attempt (of course only partial) to supplement the camp discourse with the history of nature which it involved, as well as to transform (or at least re-orient) the narrative about these places of isolation for Cominformists through the presence of nature. Although the discussed examples are dominated by an anthropocentric view, in the women's memories we can see traces of how they dealt with the problems of the camp, including the non-human experience of participation in history. Such an

\footnotetext{
17 “Он непрестано режи, не режи него циличе, цичи, а зелен је од пакости и зла и - немоћи.”

18 “Над овим мојим светом немате никакве моћи. Бесните, али ту неможете ништа."

${ }^{19}$ In the Polish cultural space, the presence of studies on animals Anna Barcz describes even as something exotic (Barcz, 2015, 309).
} 
interpretation can be treated as the first step in the process of approaching its (difficult to reconstruct) history of nature which requires enormous openness, sensitivity and empathy.

It is also worth adding that in the memories of all prisoners there are no mentions of finding comfort in religion although such an approach had been characteristic of important writers of Russian prison literature including Fyodor Dostoyevsky or Aleksandr Solzhenitsyn (compare Kowalska, 2011, 238-248). However, this subject requires separate investigation, far beyond the capacity of this text.

Finally I would like to stress that the problem of relationships is a very important issue in women's memories. The prisoners were strongly affected by the fact that their arrest caused persecution of other family members. Women were deeply saddened that it was impossible to build closer relations with other imprisoned women. The social exclusion of women prisoners and their families continued after leaving the camp. The sense of rejection and loneliness further intensified the feeling of isolation. Women found the greatest source of calm and comfort - in nature.

\section{References}

Baratay, É. (2018). Zwierzęcy punkt widzenia. Inna wersja historii. Trans. P. Tarasewicz. Gdańsk: Wydawnictwo w Podwórku.

Barcz, A. (2015). I zwierzęta mają historię... O książe Érica Barataya. "Zoophilologica. Polish Journal of Animal Studies" no. 1, pp. 309-316.

Barcz, A. (2016). Realizm ekologiczny. Od ekokrytyki do zookrytyki w literaturze polskiej. Katowice.

Gruenwald, O. (1987). Yugoslav Camp Literature: Rediscovering the Ghost of a Nation's Past-Present-Future. "Slavic Review" vol. 46, no. 3/4, pp. 513-528.

Jambrešić-Kirin, R. (2009). Komunističko totalitarno nasilje: žene na Golom otoku i sv. Grguru. http://sjecanjazena.eu/renata-jambresic-kirin-komunisticko-totalitarnonasilje-zene-na-golom-Otoku-i-sv-grguru/. 30.06.2013.

Kosić, I. (2009). Goli otok. Najveći Titov konclogor. Zagreb: Udruga Goli otok “Ante Zemljar".

Kowalska, M. (2011). Dostojewski i Solżenicyn. Droga do Boga. In: Fiodor Dostojewski i problemy kultury. Ed. A. Raźny. Kraków: Wydawnictwo Uniwersytetu Jagiellońskiego, pp. 238-248.

Krupiński, P. (2016). "Dlaczego gęsi krzyczaly?”. Zwierzęta i Zagłada w literaturze polskiej XX i XXI wieku. Warszawa: Wydawnictwo IBL PAN. 
Latour, B. (2009). Polityka natury. Nauki wkraczają do demokracji. Trans. A. Czarnacka. Warszawa: Wydawnictwo Krytyki Politycznej.

Lebl, Ž. (1990). Ljubičica bela: Vic dug dve i po godine. Gornji Milanovac: Dečje novine.

Marković, D. (1987). Istina o Golom otoku. Beograd: Narodna Knjiga.

Nikliborc, A. (2010). UwięziONE w KL Auschwitz-Birkenau. Traumatyczne doświadczenia kobiet odzwierciedlone $w$ dokumentach osobistych. Kraków: Nomos.

Petranović, B. (1988). Istorija Jugoslavije 1918-1988, vol. 3: Socijalistička Jugoslavija 1945-1988. Beograd: Nolit.

Taczyńska, K. (2014). Odzyskać przeszłość - obóz Goli otok w relacjach kobiet. Przypadek Milki Žiciny. In: Miscellanea Posttotalitariana Wratislaviensia: Postkolonializm - tożsamość - gender. Europa Środkowa, Wschodnia i Poludniowo-Wschodnia. Ed. A. Matusiak. Wrocław: Wydawnictwo Uniwersytetu Wrocławskiego, pp. 267-279.

Taczyńska, K. (2015). У потрази за стратегијама преживљавања - логорска проза Милке Жицине. “Књиженство” по. 5. http://www.knjizenstvo.rs/magazine. php?text=158. 30.12.2018.

Taczyńska, K. (2016). Dowcip trwający dwa i pół roku. Obraz Nagiej Wyspy w serbskim dyskursie literackim i historycznym końca XX i początku XXI wieku. Warszawa: Bellerive-sur-Allier.

Taczyńska, K. (2018). A Border Biography: the Image of the Past in Eva Nahir Panić's Memories on the Example of Dane Ilić's Eva. "Studia Judaica" no. 1 (41), pp. 77-95.

Ubertowska, A. (2015). Kobiety i historia. Od niewidzialności do sprawczości (wprowadzenie). In: Kobiety i historia. Od niewidzialności do sprawczości. Eds. K. Bałżewska, D. Korczyńska-Partyka, A. Wódkowska, Gdańsk: Wydawnictwo Uniwersytetu Gdańskiego, s. 7-24.

Žicina, M. (2002). Sve, sve, sve.... Zagreb: Prosvjeta.

Вукмановић, Љ. (2009). Самоће Милке Жицине. In: М. Жицина. Сама. Београд: Службени гласник, pp. 5-16.

Гароња Радованац, С. (2003). Праштање човеку, власти и идеологији (поводом романа Милке Жищине „Све, све, све” о страдању уженском логору у Стоиу). "Наш траг” по. 1/03, pp. 135-152.

Гароња Радованац, С. (2012). Резолуција Информбироа (ИБ) 1948. у српској књижевности коју пишу жене (Из рукописне заоставштине Милке Жицине). “Књижевна историја" по. 147, pp. 367-397.

Денић, С. (2005). Кюижевност и логори. Larus argentatus - вечни лет Вере Ценић. In: С. Денић, Опите и лично. Огледи о књижевности. Београд: Филип Вишњић, pp. 61-72.

Жицина, М. (2009). Сама. Београд: Службени гласник.

Михаиловић, Д. (1990). Голи оток, књ. 1. Београд: Политика.

Ценић, В. (1994). Кањец фиљма. Повест. Врање: Повест. 